\title{
A fresh look at angiogenesis in juvenile idiopathic arthritis
}

\author{
JOANNA ŚWIDROWSKA-JAROS, ELŻBIETA SMOLEWSKA
}

Department of Paediatric Cardiology and Rheumatology, Medical University of Lodz, Poland

\begin{abstract}
Angiogenesis is the complex process of creating new capillaries from preexisting blood vessels due to hypoxemia, injury or inflammation of the tissues. Numerous cytokines and cell mediators have been identified to induce and stimulate angiogenesis, but vascular endothelial growth factor $(V E G F)$ is a key regulator. The role of proangiogenic factors in the pathogenesis of chronic arthritis is currently a subject of intensive investigations in adult patients with rheumatoid arthritis (RA) and, to a limited extent, in children with juvenile idiopathic arthritis (JIA). Recent studies has shown a significant correlation between proangiogenic marker concentrations and the severity of inflammation in either RA or JIA patients. The serum neovascularization markers correlate with the power Doppler ultrasound image of the inflamed joint and hypertrophic synovium, which may be connected with the disease activity.

The aim of this paper is to describe the state of the art on the important role of angiogenesis in adult and childhood rheumatoid arthritis.
\end{abstract}

Key words: angiogenesis, juvenile idiopathic arthritis, rheumatoid arthritis, ultrasound.

(Centr Eur J Immunol 2018; 43 (3): 325-330)

\section{Introduction}

Angiogenesis is the complex process of creating new capillaries from preexisting blood vessels due to hypoxemia, injury or inflammation of the tissues. In normal tissues, angiogenesis is a self-controlled and self-limiting process and is essential for proper functioning of the body. In pathologically altered tissues, the balance between the activity of pro- and anti-angiogenic factors is impaired [1-4].

The proangiogenic mechanism is diverse - the cells stimulate proliferation and maturation of endothelial cells, degrade the extracellular matrix or affect the maturation of blood vessels $[5,6]$. The role of angiogenesis in the neoplastic process is the most prominent, but its effect is also observed in non-cancerous diseases such as asthma, psoriasis, obesity, diabetic retinopathy and rheumatoid arthritis (RA) [7].

Juvenile idiopathic arthritis (JIA) is a heterogeneous group of arthritis of unknown etiology that begins before the age of 16 and lasts continuously for a period of six weeks. It is the most common inflammatory disease of the connective tissue in developmental age. It leads to progressive and sometimes permanent and irreversible damage to the musculoskeletal system [8-11].

The pathogenesis of JIA is multifactorial. Various disorders - environmental, genetic and complex immune system - are involved in the development of the disease [12-17]. Although the exact cause of this disease is still unknown, the role of various pro-inflammatory cytokines including tumor necrosis $\alpha$ (TNF- $\alpha$ ), interleukin 1 (IL-1) and interleukin 6 (IL-6) is confirmed [18, 19].

Therefore, it is very important to establish a quick and accurate diagnosis. The course of the illness leads to many immunological disorders, including autoantibody production and cytokine imbalance. Infectious agents may further modify the immune response. Correct treatment inhibits the development of the disease [20].

Results of the recent studies showed a significant correlation between levels of proangiogenic factors and JIA activity. In this review we discuss the role of angiogenesis in JIA patients.

\section{Angiogenesis markers}

Numerous cytokines and cell mediators have been identified to stimulate the angiogenesis process (Fig. 1). The proangiogenic mechanism is variable - the cells stimulate proliferation and maturation of endothelial cells (fibroblast growth factor, vascular endothelial growth factorVEGF, insulin-like growth factor-1), degrade extracellular matrix (metalloproteinases, IL-8) or affect the maturation of blood vessels (platelet-derived growth factor).

Vascular endothelial growth factor is a key regulator of angiogenesis. The VEGF family consists of VEGF-A (commonly referred to as VEGF), VEGF-B,

Correspondence: Prof. Elżbieta Smolewska, Department of Paediatric Cardiology and Rheumatology, Medical University of Lodz, 36/50 Sporna St., 91-738 Lodz, Poland, e-mail: e.smolewska@wp.pl Submitted: 26.07.2017; Accepted: 31.10.2017 
Hemangioblast

Angioblast

Vasculogenesis VEGF

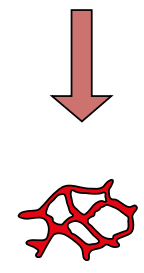

Capillaries

Angiogenesis VEGF, ANG
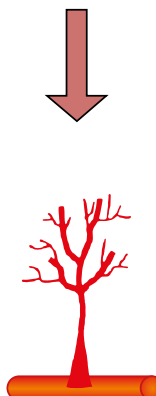

Mature vascular system

Fig. 1. Developmental angiogenesis

VEGF-C, VEGF-D, VEGF-E, VEGF-F and placental growth factor (PIGF). These molecules act on cells by binding to appropriate receptors: VEGFR-1 (Fms-like tyrosine kinase-1 - Flt-1) and VEGFR-2 (kinase domain region - KDR) located on vascular endothelial cells and VEGFR-3 (Fms-like tyrosine kinase-4 - Flt-4), present on lymphoid endothelial cells $[21,22]$. Interactions between VEGF family members and their receptors are complex and, depending on the type of connection, initiate appropriate angiogenetic pathways.

Both types of receptors are involved in angiogenesis and vasculogenesis. Although VEGF shows a higher affinity for VEGF-R1, phosphorylation of tyrosine kinase is more potent after binding to VEGFR-2, making this receptor the main receptor for VEGF activity [23, 24]. It appears that the role of VEGFR-1 is to modulate VEGFR-2 activity, acting both proangiogenically and as a "trap receptor".

The last stage of angiogenesis is maturation and stabilization of the vessel, where the angiopoietins are the involved cells. The proangiogenic effect of angiopoietin-1 (Ang-1) is to stimulate the migration of endothelial cells and activate the interaction between them and the underly- ing membrane. In addition, Ang-1 inhibits endothelial cell apoptosis [25].

Angiopoietin-2 (Ang-2) is mainly expressed in vascular remodeling sites where it is able to block Ang-1 stabilizing action. The effect of Ang-2 seems to be dependent on VEGF. Angiopoietin-2, in the absence of VEGF, causes vascular regression by induction of endothelial cell apoptosis, but in the presence of high concentrations of VEGF it activates the angiogenesis process [26-28].

\section{Role of angiogenesis in rheumatoid processes}

In the pathogenesis of rheumatoid processes, inflammatory cytokines play an important role. In the joints affected by inflammation, they maintain the inflammatory process, but also have a significant effect on angiogenesis. It leads to proliferation of synovium and pannus formation, in which numerous new blood vessels are present [29, 30].

In studies of RA patients, altered concentrations of major angiogenic factors have been demonstrated not only in synovial fluid and synovial tissues, but also in serum [31]. As a result of hypoxia, a hypoxia-induced factor $(\mathrm{HIF}-1 \alpha)$ is released and stimulates the expression of further proangiogenic factors (Fig. 2) [32, 33]. Vascular endothelial growth factor is the best known angiogenesis stimulating factor and its serum concentration correlates with the clinical picture of RA, as well as C-reactive protein (CRP) level and radiological changes in hands and feet [34]. A similar relationship has been observed in patients with JIA, but only single publications are available in the literature [35].

In addition to VEGF, proangiogenic effects in rheumatoid processes have been demonstrated for a number of other factors, including TNF- $\alpha$, IL-1, IL-6, IL-8, IL-13, IL-15, and IL-18.

Interleukin 18 stimulates the induction of angiogenesis by VEGF production and affects the endothelial cells through integrin $\alpha v \beta 3$. Moreover, it stimulates production of chemokines SDF-1/CXCL12 and MCP-1/CCL2 - complexes that promote angiogenesis in the synovial lining of the joints [36].

Tumor necrosis factor $\alpha$ has a direct effect on angiogenesis. It may also regulate angiogenesis by stabilizing the new vessels through Ang-1 and the Tie- 2 synovial membrane receptor $[37,38]$.

Angiostatin and endostatin, physiologically, act antiangiogenically by reducing VEGF concentrations. Through their influence on integrins, they interfere with the signaling necessary for the development of angiogenesis. Thrombospondin-1 (TSP-1) produced by the synovium of RA patients acts angiostatically inhibiting neovascularization and inflammation of the synovial membrane. Increased intraarticular angiogenesis is also a consequence of insufficient inhibiting effects [39, 40]. 


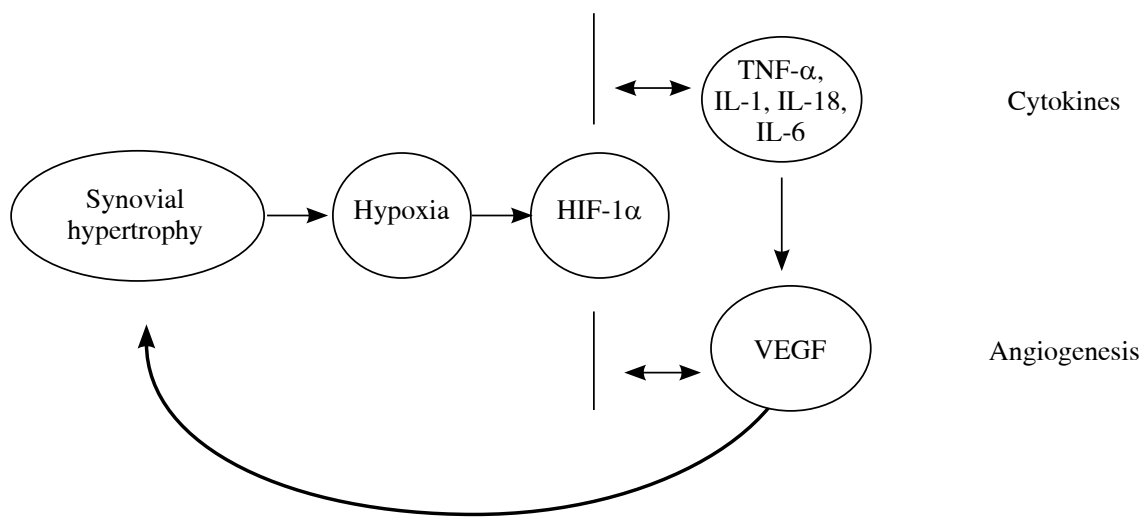

Fig. 2. The role of hypoxia in the development of angiogenesis in rheumatoid processes

Anti-angiogenic therapy is currently a new and important goal in the treatment of RA. There are many drugs that inhibit intracellular vascular formation, such as anti-VEGF antibodies (bevacizumab, vatalanib) or JAK inhibitors, but they are still under clinical trials [41].

Ultrasound examination and power Doppler mode is the gold standard in JIA diagnostics. The degree of synovial hypertrophy may be visualized, as well as the blood free movement in vessels of the synovium. It allows one to assess the activity of the inflammatory process, but also may detect subclinical and mild lesions (Fig. 3).

The inflammatory activity of the synovium detected by power Doppler imaging is correlated with inflammatory expression (erythrocyte sedimentation rate - ESR, CRP) and angiogenesis markers, primarily with VEGF. Moreover, in patients with clinical remission, persistent inflammatory activity of the synovium may be visualized, and helps in further therapeutic decisions, but it is not an early predictor of exacerbations [42-48].

\section{The current state of knowledge on the role of angiogenesis in juvenile idiopathic arthritis}

Despite a number of studies on angiogenesis and antiangiogenic therapy as a novel trend in RA, there have been few publications on the assessment of angiogenic factors in JIA so far.

High levels of VEGF and its soluble receptors have been reported several times in adult patients with RA [4852]. In studies of Maeno et al. levels of VEGF and its soluble receptors (sVEGFR-1, sVEGFR-2) in the serum of JIA patients were significantly higher compared to the healthy group [53]. Similar correlations were observed in our own studies [54]. There have been single reports concerning the VEGF concentration in the synovial fluid in children. In the research of Vignola et al. it was found that its con- centration in the articular fluid was significantly higher than in the serum concentration in JIA patients [35]. In our own studies, we observed a similar relationship between VEGF and its soluble sVEGFR-1 receptor. The inverse relationship was related to the sVEGFR-2 receptor, which could be associated with high affinity of VEGF to the Flt-1 receptor [54]. In patients with RA - contrary to the results of our research - Lee et al. found no significant difference between serum VEGF and synovial fluid taken from 32 patients [55]. Studies of Shahrara et al. on the expression of Ang-1 and Ang-2 in the synovium of RA patients revealed its significant increase. In this work the authors also observed high expression of the receptors Tie- 1 and Tie-2 in the inflamed synovium [56]. In our own studies, Ang-1 and Ang-2 concentrations were higher in the serum of patients with JIA compared to the healthy controls. In contrast to VEGF, the concentration of both angiopoietins in the synovial fluid of JIA patients was significantly lower than in serum [54]. In the work of Kurosaka et al., the role of Ang-1 was emphasized as an index of persistent arthri-

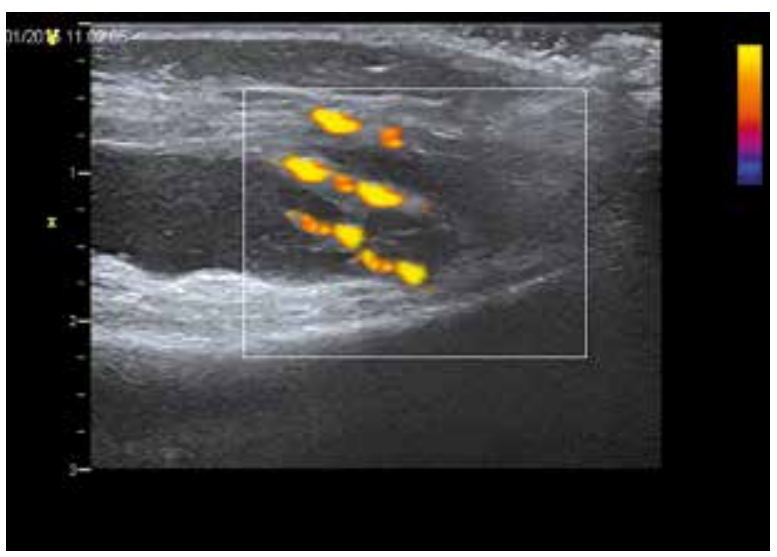

Fig. 3. Example of an ultrasound image of angiogenesis in an inflamed joint 
tis, while the increase of Ang-2 was observed only with significantly enhanced angiogenesis [57].

Maeno et al. studies showed a positive correlation between VEGF and inflammatory markers, such as CRP and ESR [53] in a population of children with oligo- and polyarthritis. Similar observations were made by Sone $e t$ $a l$. and Lee et al. in patients with RA [56, 58]. However, they did not evaluate the relationship between VEGF concentration in synovial fluid and inflammatory parameters.

Ultrasonography in rheumatology is currently a very useful tool in assessment of joint inflammation. In addition to the presence of characteristic lesions, such as synovial hypertrophy or effusion, it is possible to assess slow blood flow in the newly created vessels of the inflamed synovium by the power Doppler technique. The presence of vessels with intense flow indicates the high activity of the disease process, but also allows one to visualize the final stage of synovial angiogenesis [59-69].

Spârchez et al. attempted to correlate disease activity with the ultrasound image, confirming that high activity of inflammation is connected with a high degree of vascularization [70]. Moreover, Shanmugavel et al. and Magni-Manzoni et al. have shown that, even in clinically inactive disease, inflammatory changes in the hypertrophied synovium still remain active. This indicates the need to maintain therapy for patients in remission $[61,71]$. Magni-Manzoni et al., in a subsequent study, found that subclinical changes of joints detected in power Doppler ultrasonography are not a predictor of disease exacerbations [72].

Despite the large potential for angiogenesis assessment by power Doppler ultrasonography (PDUS) in JIA patients, there has been no work combining PDUS imaging and proangiogenic factors so far.

In studies of patients with RA, both Strunk et al. and Gok et al. did not detect any significant correlation between the concentration of VEGF and synovial neovascularization evaluated using PDUS [73, 74]. In the same work, Gok et al. found a positive correlation between Ang1 and synovial effusion, but found no such relationship with the degree of synovial vascularization. Similarly, in our own study, a significant relationship between the concentration of Ang-1 and synovial vascularization was not confirmed. Conversely, Ang-2 concentration in patients with JIA was clearly correlated with a high degree of vascularization [54].

Spârchez et al. found that a high concentration of C-reactive protein is associated with a high degree of vascularization. In our own studies we observed the same pattern [70].

The role of angiogenesis appears to be crucial in the pathogenesis of JIA. It might be proved by high levels of angiogenic factors and their correlation with disease activity. Vascular endothelial growth factor, the most specific marker of angiogenesis, reflects this correlation. Its concentration in connection with the ultrasound image of the synovium and the degree of vascularization provides information about disease activity in the early stages.

The study was supported by grant No. 503/8-451000-01/503-81-002 from the Medical University of Lodz, Poland.

The authors declare no conflict of interest.

\section{References}

1. Schrieber L, Jackson JC (1988): Angiogenesis in rheumatoid arthritis. In HJ Klippel, PA Dieppe (eds.). Rheumatology. Vol. 1. $2^{\text {nd }}$ ed. Mosby, London, UK; 1-12.

2. Ferrara N, Alitalo K (1995): Clinical applications of angiogenic growth factors and their inhibitors. Nat Med 5: 13591364.

3. Taylor PC, Sivakumar B (2005): Hypoxia and angiogenesis in rheumatoid arthritis. Curr Opin Rheumatol 17: 293-298.

4. Mizia-Malarz A, Sobol G, Woś H (2008): Angiogeneza w przewlekłych schorzeniach zapalnych i nowotworowych. Pol Merk Lek 24: 185-189.

5. Zielonka TM (2003): Angiogeneza. Część I. Mechanizm powstawania nowych naczyń krwionośnych. Alergia Astma Immunologia 8: 169-174.

6. Kurzyk A (2015): Angiogeneza - możliwości, problemy, perspektywy. Postepy Biochem 61: 25-34.

7. Cierniewski CS (2006): Regulacja angiogenezy - nowa broń w onkologii. Biol Molek 1: 20-22.

8. Prakken B, Albani S, Martini A (2011): Juvenile idiopathic arthritis. Lancet 377: 2138-2149.

9. Ravelli A, Martini A (2007): Juvenile idiopathic arthritis. Lancet 369: 767-778.

10. Rutkowska-Sak L (2014): Młodzieńcze idiopatyczne zapalenie stawów - nie tylko nowości. Termedia, Poznań; 11-14.

11. Correll CK, Binstadt BA (2014): Advances in the pathogenesis and treatment of systemic juvenile idiopathic arthritis. Pediatr Res 75: 176-183.

12. Postepski J, Opoka-Winiarska V, Koziol-Montewka M, et al. (2003): Role of Mycoplasma pneumoniae infection in aetiopathogenesis of juvenile idiopathic arthritis. Med Wieku Rozwoj 7: 271-277.

13. Barash J, Goldzweig O (2007): Possible role of streptococcal infection in flares of juvenile idiopathic arthritis. Arthritis Rheum 57: 877-880.

14. Angelini F, Cancrini C, Colavita M, et al. (2003): Role of parvovirus B19 infection in juvenile chronic arthritis. Is more investigation needed? Clin Exp Rheum 21: 684.

15. Roupe van der Voort C, Heijnen CJ, Wulffraat N, et al. (2000): Stress induces increases in IL-6 production by leucocytes of patients with the chronic inflammatory disease juvenile rheumatoid arthritis: role of putative alpha (1) - adrenergic receptors. J Neuroimmunol 110: 223-229.

16. Berkun Y, Padeh S (2010): Environmental factors and the geo-epidemiology of juvenile idiopathic arthritis. Autoimmun Rev 9: 319-324.

17. Prahalad S (2004): Genetics of juvenile idiopathic arthritis: an update. Curr Opin Rheumatol 16: 588-594.

18. Noria A, Zen M, Bestio S (2012): Autoinflammation and autoimmunity: bridging the divide. Autoimmun Rev 12: 22-30. 
19. Lin YT, Wang CT, Gershwin ME, Chiang BL (2011): The pathogenesis of oligoarticular/polyarticular vs systemic juvenile idiopathic arthritis. Autoimmun Rev 10: 482-489.

20. Correll CK, Binstadt BA (2014): Advances in the pathogenesis and treatment of systemic juvenile idiopathic arthritis. Pediatr Res 75: 176-183.

21. Ferrara N, Gerber HP, LeCouter J (2003): The biology of VEGF and its receptors. Nat Med 9: 669-679.

22. Neufeld G, Cohen T, Gengrinovitvh S, Poltorak Z (1999): Vascular endothelial growth factor (VEGF) and its receptors. FASEB J 13: 9-22.

23. Clauss M (2000): Molecular biology of the VEGF and the VEGF receptor family. Semin Thromb Hemost 26: 561-569.

24. Seetharam L, Gotoh N, Maru Y, et al. (1995): A unique signal transduction from FLT tyrosine kinase, a receptor for vascular endothelial growth factor VEGF. Oncogene 10: 135-147.

25. Kim I, Kim HG, So JN, et al. (2000): Angiopoietin-1 regulates endothelial cell survival through the phosphatidylinositol 3'-kinase/Akt signal transduction pathway. Circ Res 86: 24-29.

26. Ashara T, Chen D, Takahashi T, et al. (1998): Tie2 receptor ligands, angiopoietin- 1 and angiopoietin-2, modulate VEGF-induced postnatal neovascularization. Circ Res 83: 233-240.

27. Holash J, Maisonpierre PC, Compton D, et al. (1999): Vessel cooption, regression, and growth in tumors mediated by angiopoietins and VEGF. Science 284: 1994-1997.

28. Vajkoczy P, Farhadi M, Gaumann A, et al. (2002): Microtumor growth initiates angiogenic sprouting with simultaneous expression of VEGF, VEGF receptor-2, and angiopoietin-2. J Clin Invest 109: 777-778.

29. Koch AE (1998): Angiogenesis: implications for rheumatoid arthritis. Arthritis Rheum 41: 951-962.

30. Paleolog EM (2002): Angiogenesis in rheumatoid arthritis. Arthritis Res 4: 81-90.

31. Taylor PC, Sivakumar B (2005): Hypoxia and angiogenesis in rheumatoid arthritis. Curr Opin Rheumatol 17: 293-298.

32. Maruotti N, Cantatore FP, Crivellato E, et al. (2006): Angiogenesis in rheumatoid arthritis. Histol Histopathol 21: 557566.

33. Ballara SC, Taylor PC, Reusch P, et al. (2001): Raised serum vascular endothelial growth factor levels are associated with destructive change in inflammatory arthritis. Arthritis Rheum 44: 2055-2064.

34. Maruotti N, Cantatore FP, Crivellato E, et al. (2006): Angiogenesis in rheumatoid arthritis. Histol Histopathol 21: 557566.

35. Vignola S, Picco P, Falcini F, et al. (2002): Serum and synovial fluid concentration of vascular endothelial growth factors in juvenile idiopathic arthritis. Rheumatology 41: 691-696.

36. Park CC, Morel JC, Amin MA, et al. (2001): Evidence of IL-18 as a novel angiogenic mediator. J Immunol 167: 16441653.

37. Veale DJ, Fearon U (2006): Inhibition of angiogenic pathways in rheumatoid arthritis: potential for therapeutic targeting. Best Pract Res Clin Rheumatol 20: 941-947.

38. Szekanecz Z, Besenyei T, Paragh G, Koch AE (2009): Angiogenesis in rheumatoid arthritis. Autoimmunity 42: 563-573.

39. Lainer-Carr D, Brahn E (2007): Angiogenesis inhibition as a therapeutic approach for inflammatory synovitis. Nat Clin Pract Rheumatol 3: 434-442.
40. Kurosaka D, Yoshida K, Yasuda J, et al. (2007): The effect of endostatin evaluated in an experimental animal model of collagen-induced arthritis. Scand J Rheumatol 36: 434-441.

41. Tas SW, Maracle CX, Balogh E, Szekanecz Z (2016): Targeting of proangiogenic signaling pathways in chronic inflammation. Nat Rev Rheumatol 12: 111-112.

42. Kitchen J, Kane D (2015): Greyscale and power Doppler ultrasonographic evaluation of normal synovial joints: correlation with pro- and anti-inflammatory cytokines and angiogenic factors. Rheumatology (Oxford) 54: 458-462.

43. Ramirez J, Ruiz-Esquide V, Pomés I, et al. (2014): Patients with rheumatoid arthritis in clinical remission and ultrasound-defined active synovitis exhibit higher disease activity and increased serum levels of angiogenic biomarkers. Arthritis Res Ther 16: R5.

44. Strunk J, Heinemann E, Neeck G, et al. (2004): A new approach to studying angiogenesis in rheumatoid arthritis by means of power Doppler ultrasonography and measurement of serum vascular endothelial growth factor. Rheumatology (Oxford) 43: 1480-1483.

45. Lanni S, Wood M, Ravelli A, et al. (2013): Towards a role of ultrasound in children with juvenile idiopathic arthritis. Rheumatology (Oxford) 52: 413-420.

46. Collado P, Jousse-Joulin S, Alcalde M, et al. (2012): Is ultrasound a validate imaging tool for the diagnosis and management of synovitis in juvenile idiopathic arthritis? A systematic literature review. Arthritis Care Res 64: 1011-1019.

47. Spârchez M, Fodor D, Miu N (2010): The role of Power Doppler ultrasonography in comparison with biological markers in the evaluation of disease activity in juvenile idiopathic arthritis. Med Ultrason 12: 97-103.

48. Magni Manzoni S, Scirč CA, Ravelli A, et al. (2013): Ultrasound-detected synovial abnormalities are frequent in clinically inactive juvenile idiopathic arthritis, but do not predict a flare of synovitis. Ann Rheum Dis 72: 223-228.

49. Clavel G, Bessis N, Lemeiter D, et al. (2007): Angiogenesis markers (VEGF, soluble receptor of VEGF and angiopoietin-1) in very early arthritis and their association with inflammation and joint destruction. Clin Immunol 124: 158-164.

50. Taylor PC (2005): Serum vascular markers and vascular imaging in assessment of rheumatoid arthritis disease activity and response to therapy. Rheumatology (Oxford) 44: 721-728.

51. Salvador G, Sanmarti R, Gil-Torregrosa (2006): Synovial vascular patterns and angiogenic factors expression in synovial tissue and serum of patients with rheumatoid arthritis. Rheumatology (Oxford) 45: 966-971.

52. Sone H, Sakauchi M, Takahashi A (2001): Elevated levels of vascular endothelial growth factor in the sera of patients with rheumatoid arthritis. Correlation with disease activity. Life Sci 69: 1861-1869.

53. Maeno N, Takei S, Imanaka H (1999): Increased circulating vascular endothelial growth factor is correlated with disease activity in polyarticular juvenile rheumatoid arthritis. J Rheumatol 26: 2244-2248.

54. Świdrowska J, Smolewski P, Stańczyk J, Smolewska E (2015): Serum angiogenesis markers and their correlation with ultrasound-detected synovitis in juvenile idiopathic arthritis. J Immunol Res 2015: 741457.

55. Lee SS, Joo YS, Kim WU, et al. (2001): Vascular endothelial growth factor levels in the serum and synovial fluid of patients with rheumatoid arthritis. Clin Exp Rheumatol 19: 321-324. 
56. Shahrara S, Volin MV, Connors MA, et al. (2002): Differential expression of the angiogenic Tie receptor family in arthritic and normal synovial tissue. Arthritis Res 4: 201-208.

57. Kurosaka D, Hirai K, Nisioka M, et al. (2010): Clinical significance of serum levels of vascular endothelial growth factor, angiopoetin-1 and angiopoetin-2 in patients with rheumatoid arthritis. J Rheumatol 37: 1121-1128.

58. Sone H, Sakauchi M, Takahashi A (2001): Elevated levels of vascular endothelial growth factor in the sera of patients with rheumatoid arthritis. Correlation with disease activity. Life Sci 69: 1861-1869.

59. Lanni S, Wood M, Ravelli A, et al. (2013): Towards a role of ultrasound in children with juvenile idiopathic arthritis. Rheumatology (Oxford) 52: 413-420.

60. Rebollo-Polo M, Koujok K, Weisser C, et al. (2011): Ultrasound findings on patients with juvenile idiopathic arthritis in clinical remission. Arthritis Care Res 63: 1013-1019.

61. Magni-Manzoni S, Epis O, Ravelli A (2009): Comparison of clinical versus ultrasound-determine synovitis in juvenile idiopathic arthritis. Arthritis Rheum 61: 1497-1504.

62. Magni-Manzoni S, Mallattia C, Lani S, Ravelli A (2012): Advances and challenges in imaging in juvenile idiopathic arthritis. Nat Rev Rheumatol 8: 329-336.

63. Speed CA, Bearcroft PW (2002): Musculoskeletal sonography by rheumatologists: the challenges. Rheumatology 41 : 241-242.

64. Szkudlarek M, Court-Payen M, Jacobsen S, et al. (2003): Interobserver agreement in ultrasonography of the finger and toe joints in rheumatoid arthritis. Arthritis Rheum 48: 955962.

65. Scheel AK, Hermann KG, Kahler E, et al. (2005): A novel ultrasound synovitis scoring system suitable for analyzing finger joint inflammation in rheumatoid arthritis. Arthritis Rheum 2005; 52: 733-743.

66. Fernandes EA, Junior MR, Mitraud AS, et al. (2008): Ultrasonografia na artrite reumatoide: aplicabilidade e perspectivas. Rev Bras Reumatol 48: 25-30.

67. Collado P, Naredo E, Calvo C, Crespo M (2007): Assessment of the joint recesses and tendon sheaths in healthy children by high-resolution B-mode and Power Doppler sonography. Cin Exp Rheumatol 5: 915-921.

68. Vlad V, Micu M, Porta F, et al. (2012): Ultrasound of the hand and wrist in rheumatology. Med Ultrason 14: 42-48.

69. Taljanovic MS, Melville DM, Gimber LH, et al. (2015): High-resolution US of rheumatologic diseases. Radiographics 7: 2026-2048.

70. Spârchez M, Fodor D, Miu N (2010): The role of Power Doppler ultrasonography in comparison with biological markers in the evaluation of disease activity in juvenile idiopathic arthritis. Med Ultrason 12: 97-103.

71. Shanmugavel C, Sodhi KS, Sandhu MS, et al. (2008): Role of power Doppler sonography in evaluation of therapeutic response of the knee in juvenile idiopathic arthritis. Rheumatol Int 28: 573-578.

72. Magni Manzoni S, Scirč CA, Ravelli A, et al. (2013): Ultrasound-detected synovial abnormalities are frequent in clinically inactive juvenile idiopathic arthritis, but do not predict a flare of synovitis. Ann Rheum Dis 72: 223-228.
73. Strunk J, Heinemann E, Neeck G, et al. (2004): A new approach to studying angiogenesis in rheumatoid arthritis by means of power Doppler ultrasonography and measurement of serum vascular endothelial growth factor. Rheumatology (Oxford) 43: 1480-1483.

74. Gok M, Erdem H, Gogus F, et al. (2013): Relationship of ultrasonographic findings with synovial angiogenesis modulators in different forms of knee arthritides. Rheumatol Int 33: 879-885. 